\title{
THE COMPETITIVENESS OF TOURISM IN ROMANIA AFTER EU ACCESSION - REGIONAL ANALYSIS
}

\author{
Elisabeta Rosuㄹ , Dan-Marius Voicilas ${ }^{2}$ \\ *Corresponding author E-mail: dmvoici@yahoo.com
}

A R T I C L E I N F O
Review Article
Received: 11 February 2019
Accepted: 10 December 2019
doi:10.5937/ekoPolj1904023R
UDC 338.48(498)(4-672EU)
Keywords:
Tourism, Competitiveness,
Romania, Regional analysis, EU
accession

JEL: L83, R11

\section{A B S T R A C T}

Tourism is dependent on the existence of natural and antrophic resources. Because Romania is characterized by great variety and diversity of these type of resources, we want to study the evolution and attractiveness of tourism and how it was influenced by the EU accession. The analysis is focused on two important touristic regions of Romania, namely Nord-Est and Sud-Est. For this approach, we use the comparative analysis, in dynamics, of the main indicators used in tourism activity, based on statistical data at regional and national level. The results of the analysis will highlight the potential and attractiveness of tourism and the advantages of Romania's EU membership.

(C) 2019 EA. All rights reserved.

\section{Introduction}

With balanced relief and accessible geographic location, Romania meets all the conditions to become a competitive tourist attraction not only at regional level, but also at international level. In Romania, "there are rich natural and anthropic resources, with various and diverse objectives of national and international interest, with special landscape areas, with natural reserves and protected areas" (Voicilas, 2017). The various forms of relief give Romania a great variety of natural tourist attractions. "The complexity of natural tourism potential and attractiveness are closely correlated with the particularities of topography and climate" (Niță, Niță, 2008). In the same time, there are different antrophic attractions in all its regions, with different historical influences that make them attractive. "The anthropic tourism potential of a tourism destination sums up people's achievements throughout the history, materialized into elements of culture, history, art and civilization, which are attracting tourist flows" (Stănciulescu, Micu, 2009). There are cultural and architectural influences, or other kind of influences from

1 Elisabeta Roşu PhD, Senior researcher, Romanian Academy, Institute of Agricultural Economics, Bucuresti, Romania, Calea 13 Septembrie no.13, sector 5, betty_rosu@yahoo.com, ORCID ID: 0000-0003-2100-3481

2 Dan-Marius Voicilaş, Assoc. Prof. PhD, Senior researcher, Romanian Academy, Institute of Agricultural Economics, Bucuresti, Romania, Calea 13 Septembrie no.13, sector 5, dmvoici@yahoo.com, ORCID ID: 0000-0003-3411-8958

http://ea.bg.ac.rs 
Slavic world in East regions of Romania, Germanic world influences in West regions of Romania or Balkan and Turkish influences in South regions of Romania. With all of these conditions, the Romanian tourism after 1989 did not progressed "despite its high potential for tourism, Romania is not yet able to develop an efficient tourism" (Popescu, 2016). There were many factors that influenced the decline. Among them, we want to mention the lack of investments and marketing and "the absence of a general policy for tourism sector management and orientation" (Romanian Government, 2007).

The transition process from state-controlled tourism to private business was a challenge for the entrepreneurs from many points of view, in a very competitive world. There are strengths and weaknesses, but also opportunities and challenges that the Romanian entrepreneurs must face. Slowly, since 2000, after Romania started the European Union (EU) accession negotiations, tourism industry received much more importance, both from investors and state administration points of view, as well "potential exists, but without the involvement of central and local authorities it is not possible to develop a well-defined tourist accommodation network" (Stanciu, 2007). A positive influence in this process had the possibility for entrepreneurs to access the pre-accession funds for tourism activities. It was a very useful period for start-up business and diversification and modernisation of existing investments, a welcomed preparation for the next stages, the EU membership and the tough competition from the EU member-states.

The objective of this paper is to analyse the tourism activity after Romania joined the EU, as the EU membership has created new development possibilities. We want to identify the main factors of influence of the tourism activity in Romania and for the purpose of this study, we chose two regions, which differ from each other and are much diversified from the tourism point of view, namely Nord-Est (North-East, NE) and Sud-Est (South-East, SE), considered representative. In the same time, we want to identify the main measures that are necessary to improve the present state of the sector, which are the best practices, policies and strategies that can help the sector to reach a competitive level in EU.

\section{Materials and methods}

The methodology comprised the statistical analysis of primary data using Excel quantitative analysis program as working tool. The statistical data on which the analysis was based were national data and data for two development regions: NE and SE, which covered the period 2007-2015 and had the following sources: i) statistical data from the National Institute of Statistics (INS) available online - www.tempo-online; ii) the web sites of the North-East and South-East Regional Development Agencies; iii) other official sources. The first part of the study contains a brief characterization of the two development regions, and we focus on the natural and anthropic potential; the second part contains the analysis of the main indicators of the tourism activity: tourist receival structure, tourist accommodation capacity in operation, tourist arrivals and overnight stays. On the basis of these synthetic indicators of tourism activity we calculated: 
a. net utilization index of the tourist accommodation capacity in operation, according to the formula: $I_{n}=\left(N / C_{f}\right) \times 100$, where: $I_{n}$ is the net utilization index of the tourist accommodation capacity in operation; $\mathrm{N}$ is the number of overnight stays in a certain period; $\mathrm{C}_{\mathrm{f}}$ is the tourist accommodation capacity in operation;

b. average length of stay, according to formula: $\mathrm{DM}=(\mathrm{Nin} / \mathrm{Ns})$, where: $\mathrm{Nin}$ is the number of overnight stays, and Ns is the number of tourist arrivals in a certain period.

The study also starts from the authors' previous research works, among which we would like to mention Kravtsiv, Borshchevskyy, Voicilaş, Rusu, 2015, Voicilaş, 2017 and Roşu, 2016.

\section{Results}

The analysis of specific indicators for the tourism activity in the two regions of Romania in the period 2007-2015 highlighted the evolutions registered and led to a series of conclusions. The two regions, with extremely different natural and anthropogenic potentials, have evolved from a different tourism point of view. Thus, from the point of view of the analysed indicators, in many cases the South-East Region has evolved in the opposite direction to the North-East Region, having most often a positive trend. The same opposite and positive trend were also noticed as compared to the evolution of the same indicators at national level, which justifies us to say that this region has some clear comparative advantages. Moreover, the two indices calculated at the end of the article (net use index of accommodation capacity and the average length of stay) come to tally with the conclusions outlined above. What factors influenced these developments, also in which way and proportion, will be analysed and detailed in the chapters of this article.

\section{Discussions}

\section{Tourism potential of the development regions North-East and South-East}

\section{Description of regions}

The North-East Region borders on Ukraine in the north, on the South-East Region in the south, on the North-West Region in the west and on Republic of Moldova in the east. Its total area is $36,800 \mathrm{~km}^{2}$ and consists of 6 counties: Bacău, Botoani, Iai, Neamţ, Suceava and Vaslui. It is the largest among the eight development regions of Romania, both in terms of area (15.5\% of Romania's total area) and of population, accounting for $16.5 \%$ of the country's total population in 2015 (INS).

The relief of the region is characterized by a mix of three relief units: about $30 \%$ mountains, $30 \%$ hills and $40 \%$ plateau. The different relief units create climate areas with significant differences between the mountainous, hilly and plain areas.

The hydrographical network consists of eight major water courses, among which the largest hydrographical basins are those of the Siret and Prut rivers, the latter 
forming a natural border between Romania and the Republic of Moldova (NorthEast ARD, 2014).

The region South-East borders on the North-East Region in the north, on the Centre Region in the west, on the Sud-Muntenia Region and Bucharest-Ilfov Region in the south-west and on the Republic of Moldova, Ukraine and the Black Sea in the east. Its total area is $35,762 \mathrm{~km}^{2}$, covering $15 \%$ of the country's total area; it is the second largest region in the 8 development regions of Romania. The region has 6 counties in its componence: Brăila, Buzău, Constanța, Galați, Tulcea and Vrancea. In the year 2015, the region's population accounted for $12.5 \%$ of Romania's population (INS).

Figure 1. Map of North-East and South-East Regions

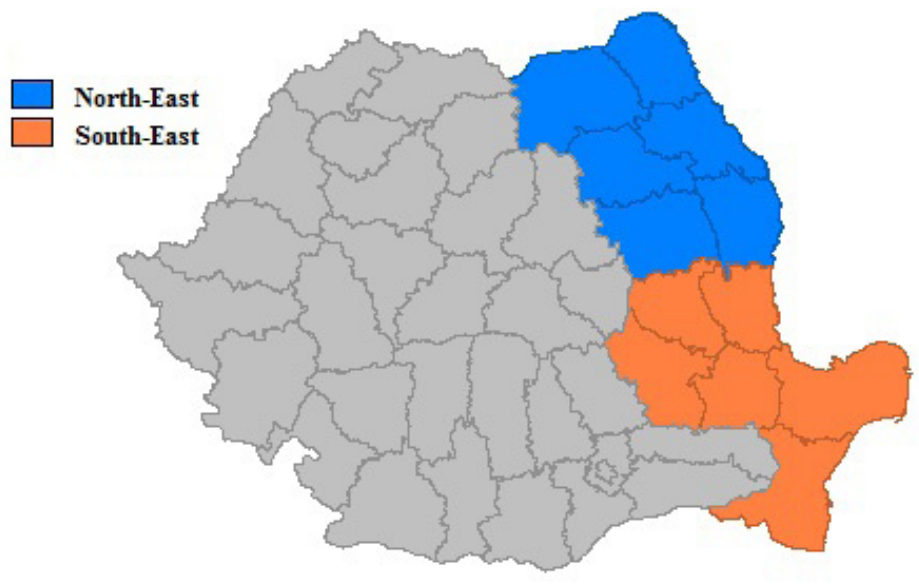

Source: own representation based on GIS software GeoDa

All the relief units can be found in the South-East Region: river plain (the Danube River Plain), plain (Bărăgan Plain), plateau (Dobrogea Plateau), mountains (the Carpathians Mountains - the Carpathians and the Curvature Sub-Carpathians, Măcinului Mountains). The region's climate is of temperate continental type, yet with significant variations depending on the relief. The region is crossed by Danube River and it is bordered by the Black Sea coast in its eastern part, with a length of $245 \mathrm{~km}$. At the place where the Danube flows into the Black Sea, the Danube Delta was formed, which, together with the Black Sea, are specific only to this region (South-East ARD, 2014).

\section{Natural potential in the two regions}

In the North-East Region the history, culture and tradition complement the extremely attractive natural environment.

There are many natural reserves and nature monuments in this region, protected natural areas of national interest, and 3 out of the 13 national parks of Romania, namely: National Park "Călimani Mountains", National Park "Cheile Bicazului-Hăşmaş", 
National Park "Ceahlău”. The natural reserves and nature monuments from the region North-East, 126 in number, lies on 49,183 ha. The ecologic network "Natura 2000" comprises 55 natural areas.

The climate of the region North-East is suitable for therapeutic treatments, including areas with a tonic, sedative and saline bioclimate. The balneary factors are valorised by numerous sources of therapeutic mineral waters used in internal and external cures, the therapeutic gases (used for the treatment of cardio-vascular diseases) and the saltwater springs (Vatra Dornei, Slănic Moldova, Târgu Ocna, Sărata Băi, Durău, Câmpulung Moldovenesc, Gura Humorului, etc), which add to the existence of two salines (Târgu Ocna and Cacica) that enjoy a specific microclimate for the treatment of respiratory diseases.

The North-East Region has a rich vine growing tradition, recognized both nationwide and worldwide, with renowned vineyards (Cotnari, Bucium, Huşi), wine tasting centres and wineries (North-East ARD, 2013).

The South-East Region has a very rich natural heritage comprising protected areas, the only seaside and delta areas from Romania, therapeutic lakes and springs, together with unique natural sites in Europe (the Danube Delta and the Muddy Volcanoes).

The South-East Region ranks first in Romania as regards biodiversity conservation: on one hand, it is the region with the largest natural protected areas from Romania (45\% of total natural protected areas), and on the other hand 35\% of the region's area is covered by natural protected areas. There are 144 natural protected areas of national interest on the region's territory, including a biosphere reserve (Danube Delta Biosphere Reserve), a national park (National Park "Măcinului Mountains") and 3 natural parks (Natural Park "Balta Mică a Brăilei", Natural Park "Prutul de Jos" and Natural Park "PutnaVrancea"). The Danube Delta has a triple status: Biosphere Reserve, Ramsar Site and World Natural and Cultural Heritage Site. The Community Network "Natura 2000" comprises 133 sites, out of which 80 Special Areas of Conservation - SCI and 53 Special Protected Areas - SPA.

The region's climate is suitable for different therapeutic cures, starting from the Black Sea coast adequate for the treatment of rheumatic diseases and ending up with the mountain area in its northern part, with a clean and tonic bioclimate adequate for the treatment of respiratory and nervous system diseases. The mineral water springs with different properties, together with the therapeutic mud from lakes (Balta Albă, Lacul Sărat) represent important natural curative factors.

The most renowned vineyards and wine centres from Romania are located on the region's territory (Murfatlar, Odobeşti, Panciu, Nicoreşti, Pietroasele, etc), the region ranking first in Romania as regards the area under vines on bearing. 


\section{Anthropic potential of the two regions}

The North-East Region has 4003 historical monuments ${ }^{3}$ that include archaeological sites, buildings of historical and archaeological interest, memorial houses, and religious monuments. There are quite an impressive number of churches and monasteries in the region, which besides a religious and cultural value also have a great historical and architectural value, preserving their beauty after more than 450 years. Eight churches on the region's territory are in UNESCO world heritage. Besides these, we can also find in the region: fortresses (Seat Fortress of Suceava, Neamț Citadel), princely courts (Princely Court of Suceava, Princely Court of Piatra Neamț), palaces (Ghica Palace, Princely Palace of Alexandru Ioan Cuza, Sturza Palace, Duke Palace), manor houses (Cantacuzino manor house) and princely houses (North-East ARD, 2006).

The South-East Region is part of a space with a very rich history, which left behind a heritage of cultural vestiges and gave birth to a specific ethnical and cultural diversity. 3000 historical monuments are located here ${ }^{4}$, the cultural heritage consisting of: historical vestiges (the Getic citadel Troesmis, the Roman fortress Dinogeția, Argamum citadel, the Roman citadel Halmyris, the Roman castrum Noviodunum, Enisala citadel, the Roman castra Carsium and Capidava, the Roman citadel Tropaeum Traiani, the Greek citadel Histria, the oldest attested town on Romania's territory, the archaeological site Tomis, the Greek citadel Calatis), religious establishments (Orthodox, Catholic, GreekCatholic, Armenian, Evangelical churches, Orthodox monasteries and hermitages, mosques and synagogues,) as well as cultural establishments, monuments and museums (South-East ARD, 2014).

Due to the natural conditions, beautiful places, mainly in the mountains, together with the rich cultural, historical and religious heritage, which add to the folk traditions and customs, specific cuisine, tasting of wines from the regions' vineyards, both regions have high tourism potential, but "the essential requirement is that, this potential is best put into value by the suppliers of tourism products and services" (Rosu, 2016).

\section{Indicators of tourist circulation}

In this chapter, we investigate the main indicators of tourist circulation, and on this basis, we briefly outline the tourist trends in the two regions and the main factors that have determined the respective evolutions. Among the existing indicators, we selected the following: tourist receival structures, tourist accommodation capacity in operation, Romanian and foreign tourist arrivals, Romanian and foreign tourist overnight stays, net utilization index of accommodation capacity and average length of stay.

3 Grouped into two categories according to Romania's legislation into effect: historical monuments of national or universal value (category A) and historical monuments representative for the local cultural heritage (category B), according to the Ministry of Culture and National Identity, List of Historical Monuments, Order of the Minister of Culture no. 2828 of 2015.

4 Order of the Minister of Culture no. 2828 of 2015. 
In the investigated period, the number of tourists' receival structures was lower in the North-East Region than in the South-East Region, with an increasing trend for NorthEast and a decreasing trend for the South-East.

This decrease, which was manifested only in the year 2011, is explained by the effects of the legislative changes in that year regarding meeting the criteria of obtaining the (re)accreditation/ authorizations as tourism operators. These changes mainly affected the agro-tourism boarding houses, bungalows, tourist house-lets, motels, tourist villas, children camps that are mainly found in the Black Sea shore area.

In the year 2007, the tourist receival structures in the two development regions together accounted for $36.3 \%$ of total tourist receival structures at national level, while in the year 2015 they accounted for $28.5 \%$.

Figure 2. Tourist receival structures with accommodation functions in the two regions

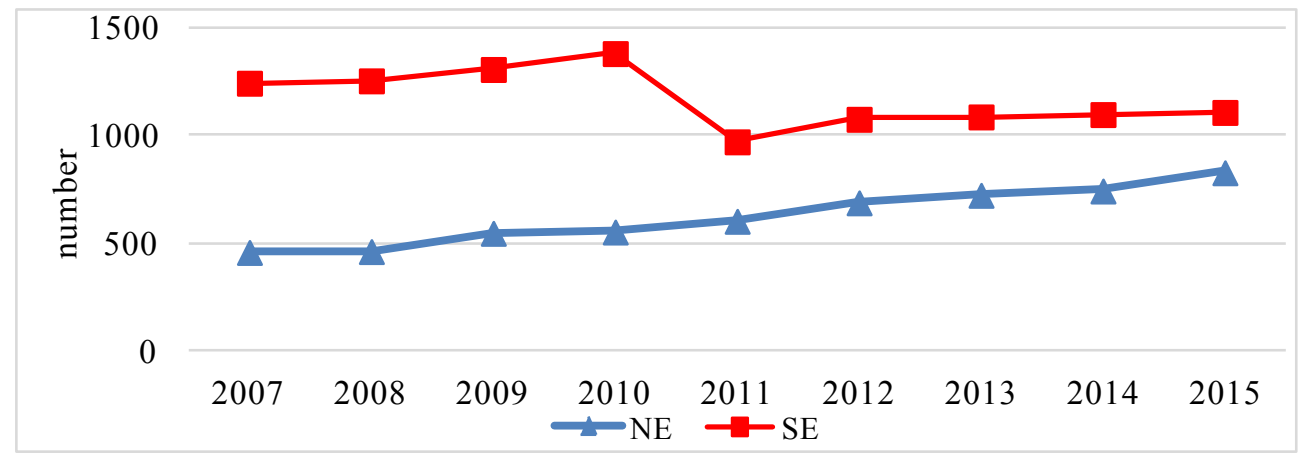

Source: based on INS data, www.tempo-online (TUR101D)

In the period 2007-2015 in the North-East Region the number of tourists receival structures significantly increased for all types of structures, except for camping and school camps. In the tourist receival structures, the tourist and agro-tourist boarding houses had the highest share, $61 \%$ of total in the year 2007; in the year 2015, their share increased by $4 \%$.

The existence and mainly the increase in number of tourist and agro-tourist boarding houses in the North-East Region reveals the development of entrepreneurial spirit in the tourism sector. The tourist boarding houses and agro-tourist boarding houses in particular are in the rural area, and tourism activity in the rural area represents an economic alternative for the rural people. The existence of a great number of tourists' receival structures in the year 2007 is a consequence of accessing the European pre-accession programs (SAPARD). The fact that in the year 2015 the number of these categories of tourist receival structures grew significantly is a consequence of Romania's EU membership and of using the non-refundable financing for the tourism sector development.

In the investigated period, even though in the South-East Region the total number of tourists receival structures followed a decreasing trend, the number of hotels, hostels, 
motels and tourist halting places increased. The remaining tourist receival structures decreased in number, except for the number of inns and holiday villages that remained constant in the investigated period.

In the South-East Region, the hotels prevailed in the tourist receival structures, accounting for $32.2 \%$ in the year 2007 and $37.6 \%$ respectively in 2015 in total structures. The tourist villas followed next, accounting for $28.6 \%$ in 2007 and $24.3 \%$ in 2015 of total tourist receival structures.

The accommodation spaces on river and sea vessels, along the Danube riverbanks, are specific to the South-East Region. The bungalows, made from wood or masonry, are tourism structures operating on seasonal basis. The great number of such structures, usually located on the Black Sea shore and in the Danube Delta, reveals the specificity of tourism practiced in these areas, namely summer tourism.

The touristaccommodation capacity in operation, representing the number of accommodation places put at the disposal of tourists, taking into account the number of days when the respective units are open, had positive evolutions in both development regions.

Figure 3. Tourist accommodation capacity in operation

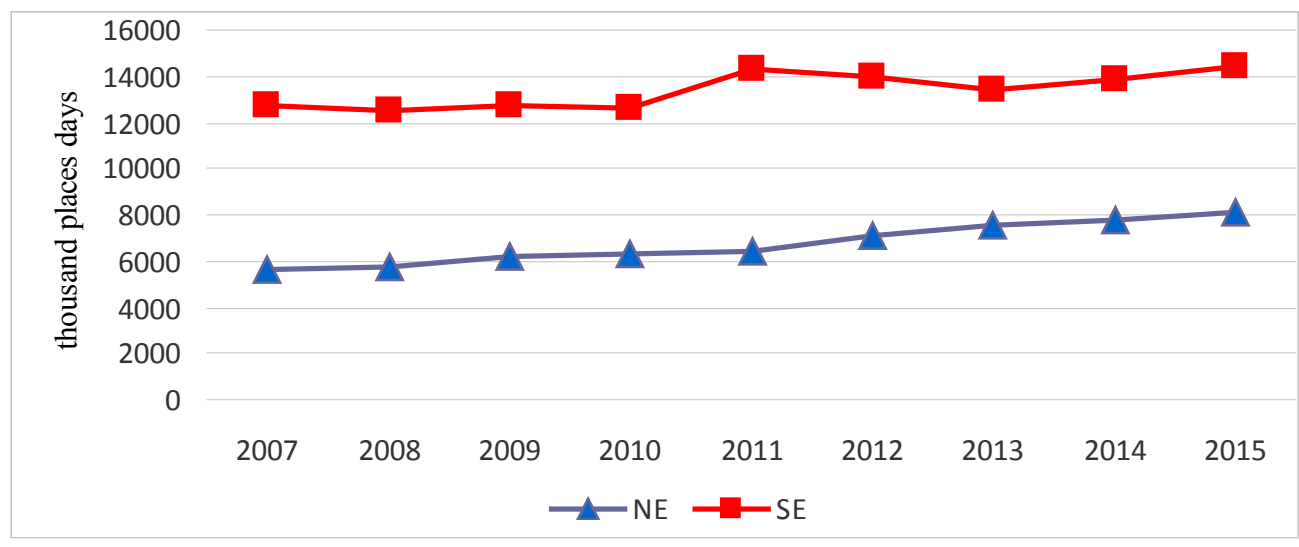

Source: based on INS data, www.tempo-online (TUR103B)

In the North-East Region, under the background of the increase in the number of tourists receival structures and of the number of places in these structures, the tourist accommodation capacity in operation was by $31 \%$ higher in 2015 as compared to the year 2007 .

It is worth mentioning that in the South-East Region, even though the number of tourist receival structures and the number of places in these structures had a negative trend, the tourist accommodation capacity in operation in the period 2007-2015 had a positive evolution, which reveals that the tourist accommodation capacity has been more efficiently used in this region.

In the year 2015 , the tourist accommodation capacity in operation was by $12 \%$ higher than in 2007 in the South-East Region. 
The number of tourists who arrived in the South-East Region was higher than the number of tourists who arrived in the North-East Region. This is explained by the presence of the Black Sea and the Danube Delta, as tourist attraction points mainly in the summertime. Although fluctuating, the number of visitors was higher in the year 2015 than in 2007 in both regions.

In the two investigated regions, similarly to the trend nationwide, the number of tourist arrivals in the tourist receival structures had an increasing trend, except for the years 2009 and 2010. The economic crisis led to the compression of tourist circulation. In the year 2007, the number of tourist arrivals in the two regions accounted for $27.9 \%$ of total, while in the year 2010 this share was $23.1 \%$ of the total number of tourists at national level.

Figure 4. Tourist arrivals in Romania and in the two regions

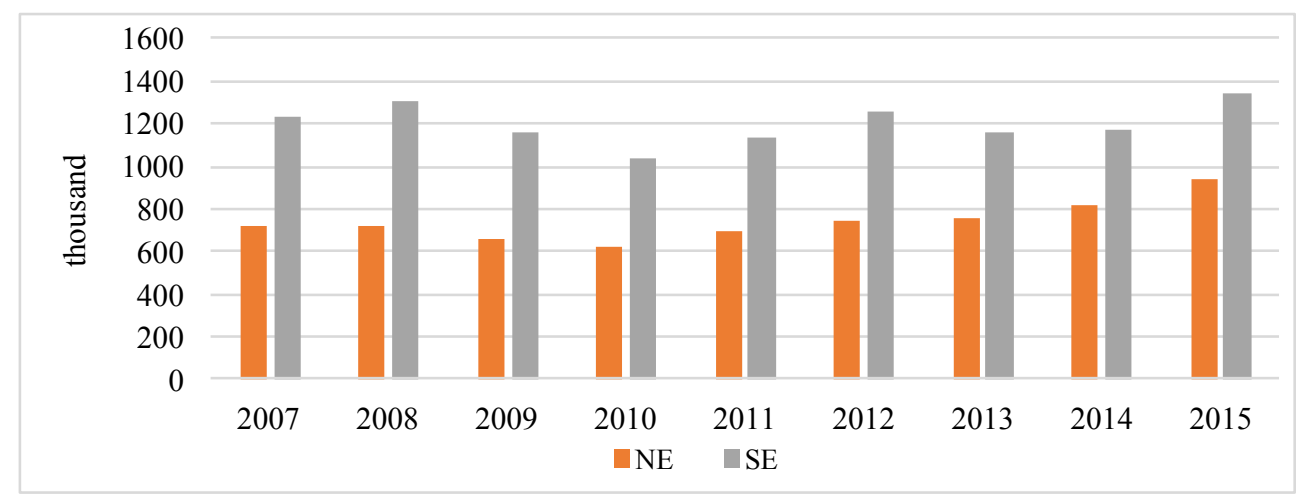

Source: based on INS data, www.tempo-online (TUR104B)

The number of the Romanian tourists who arrived in the two regions was clearly higher than the number of foreign tourists.

In the investigated period, the Romanian tourists were more attracted to visit the SouthEast Region than the North-East Region, which was proved by the much higher number of those who arrived at the seaside and in the delta. It is worth mentioning that the number of Romanian tourists who visited the two regions had a positive trend in the period 2007-2015, except for the years 2009-2010, when the economic crisis effects were felt.

The economic crisis also affected the flows of foreign tourists who visited Romania, with their number down by more than 40\% in the period 2007-2010 in both regions under analysis. 
Figure 5. Romanian tourist arrivals in the two regions

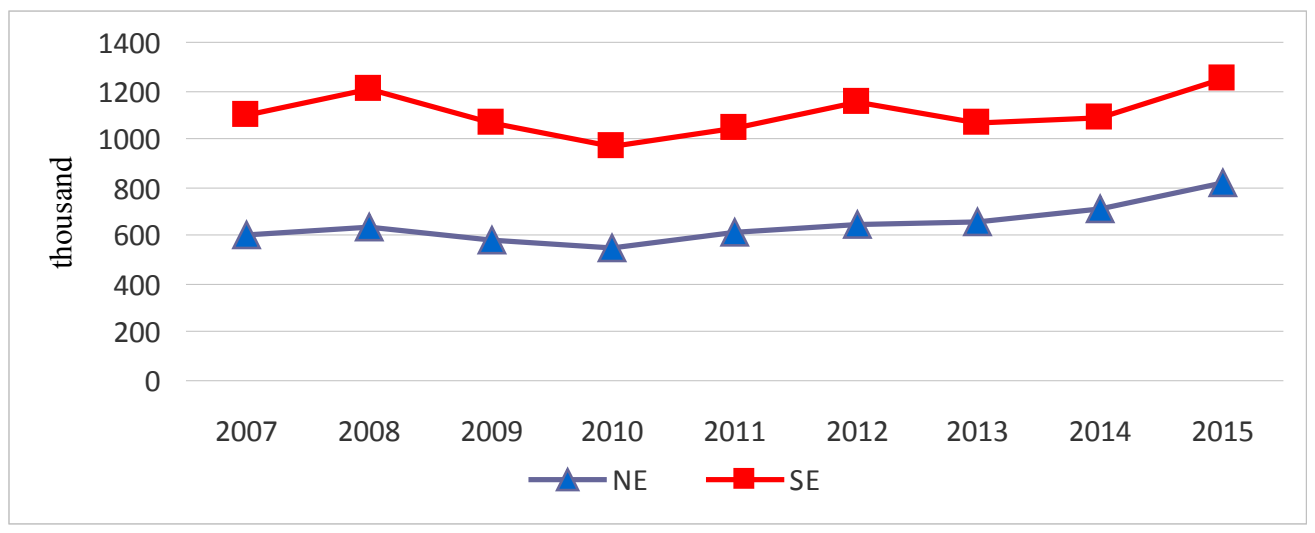

Source: based on INS data, www.tempo-online (TUR104B)

There was no significant difference between regions as regards the number of foreign tourists who chose to visit the two regions; yet we must mention that the region SouthEast was more attractive for these, except for the last two years, when the foreign tourist flows got reoriented from the Black Sea shore to other tourism objectives from the country, which were intensely promoted on the occasion of tourism fairs in recent years.

The number of foreign tourists who arrived in the South-East Region had an oscillating evolution, but in the year 2015 it was much lower than in the year 2007.

Figure 6. Foreign tourist arrivals in the two regions

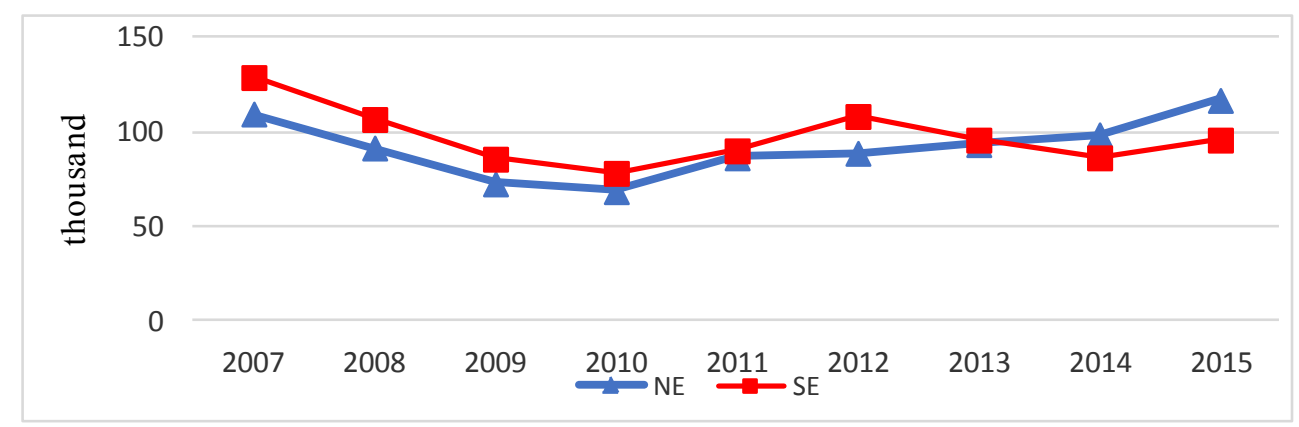

Source: based on INS data, www.tempo-online (TUR104B)

The number of tourists who stayed overnight in different tourist receival structures nationwide had an oscillating evolution; a similar evolution was also found at the level of the two development regions, in the South-East Region in particular, which has a high tourism potential, but much more exposed to fluctuations in tourists' preferences and expectations about accommodation services. Yet a difference exists. The NorthEast Region is less vulnerable as it has tourism attractions offered throughout the year, unlike the tourism seasonality specific to the seaside and the Danube Delta. 
Throughout the investigated period, about one-third of tourists who stayed overnight in different tourist receival structures opted for the two regions, which reveals once again the tourism importance of these regions. In the year 2007, the number of tourists who stayed overnight in the two regions accounted for $33.9 \%$ of the total number of tourists at national level, and 29\% in the year 2015. By comparison, a much higher number of tourists stayed overnight in the South-East Region than in the North-East Region.

Figure 7. Overnight stays of tourists in Romania and in the two regions

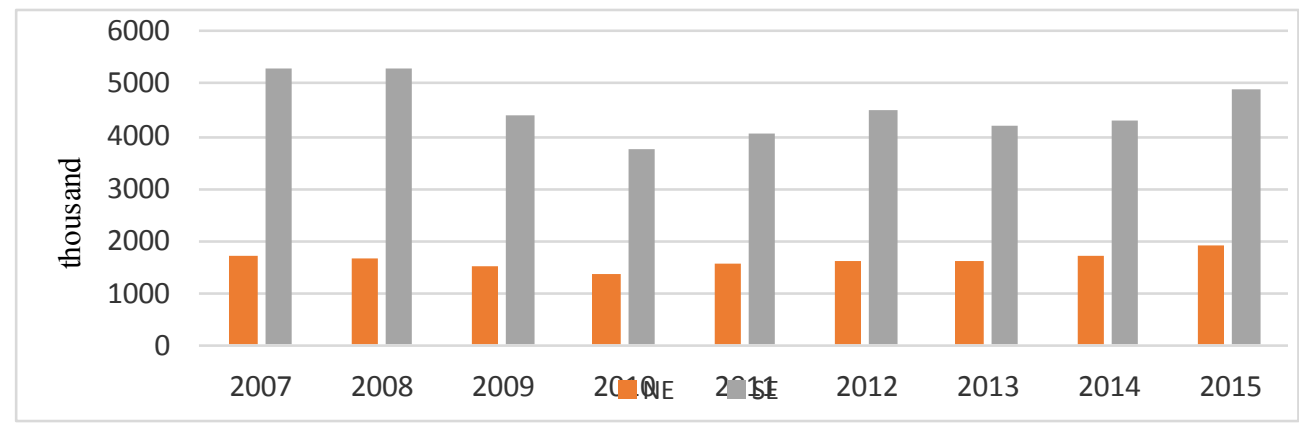

Source: based on INS data, www.tempo-online (TUR105D)

The number of overnight stays of the Romanian tourists in the South-East Region was higher than that in the North-East Region. In the investigated period, in both regions, the number of Romanian tourists' overnight stays had a fluctuating evolution, significantly down mainly in 2009 and 2010, following the outbreak of the economic crisis. It should be mentioned that in the year 2015 the number of overnight stays in the South-East Region was closer to the maximum reached in the investigated period (2008), and the region North-East had the highest number, which reveals a revigoration of tourism activities.

Figure 8. Romanian tourists' overnight stays

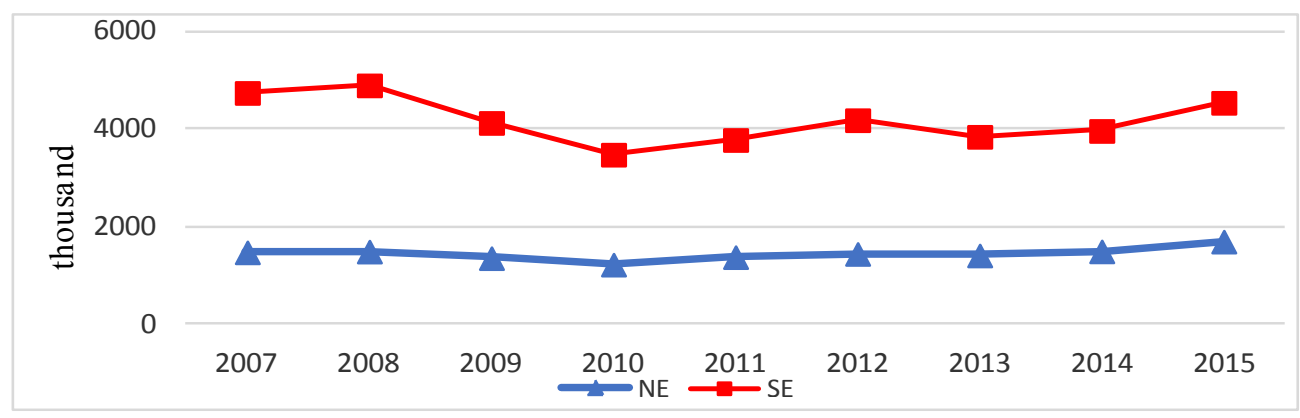

Source: based on INS data, www.tempo-online (TUR105D)

The number of foreign tourists who stayed overnight in different tourist receival structures in the South-East Region was noticeably higher than that from the North-East Region, as an effect of the richer and more attractive tourist offer, of more developed tourism structures and capacities. In the investigated period, there was an upward evolution in the North-East Region, to reach a maximum in the year 2015. 
Figure 9. Foreign tourists' overnight stays

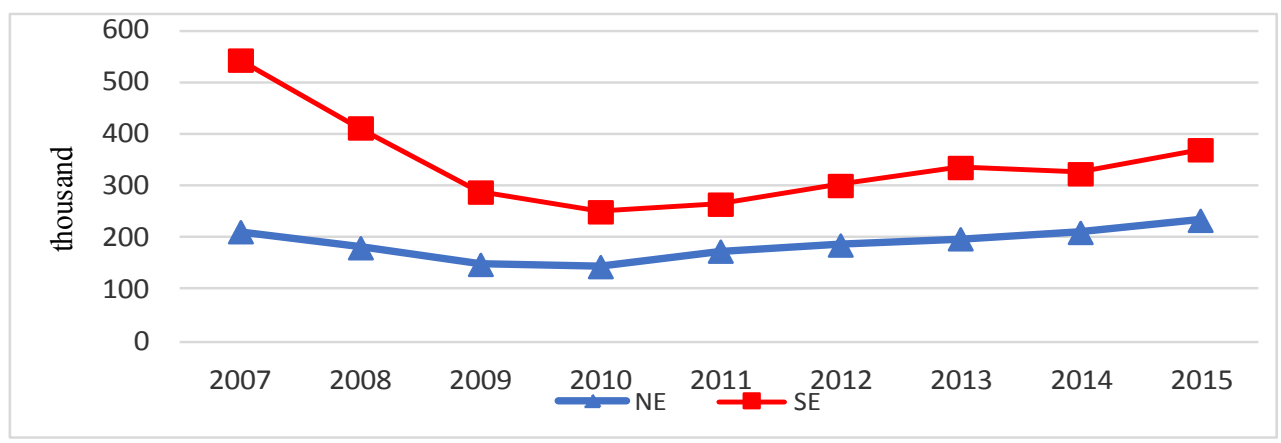

Source: based on INS data, www.tempo-online (TUR105D)

The number of foreign tourists who stayed overnight in the tourist receival structures in the South-East Region had an oscillating evolution instead, lower in 2015 as against 2007 and 2008, before the outbreak of the economic crisis. The decreasing number of the foreign tourists who opted to stay overnight in the South-East Region reveals a diminution of their interest to visit this region; the causes of this situation may be the quality of services and the relationship between the quality of services and the prices practiced.

The net use index of accommodation capacity, both nationwide and at the level of the two development regions, significantly decreased in the period 2007-2015. At national level, this index had a maximum value of $36 \%$ in the year 2007, while in the year 2015 it decreased by over $7 \%$, to reach $28.7 \%$. The same decreasing trend can be noticed for the net use index of accommodation capacity in the North-East Region, down by $7 \%$ (from 30.9\% in 2007 23.9\% in 2015) and in the South-East Region where it decreased by $7.7 \%$ (from $41.8 \%$ in 2007 to $34.1 \%$ in 2015). This decrease of the net use index of the tourist accommodation capacity, both nationwide and at the level of the two development regions, indicates that a regress in the activities in this sector took place. The decreasing level of the net use index of accommodation capacity may be attributed to the negative effects of the economic and financial crisis that led to the diminution of population's incomes and to the contraction of demand for tourism services implicitly.

Table 1. Net use index of accommodation capacity in Romania and in the two regions (\%)

\begin{tabular}{|l|c|c|c|c|c|c|c|c|c|}
\hline & $\mathbf{2 0 0 7}$ & $\mathbf{2 0 0 8}$ & $\mathbf{2 0 0 9}$ & $\mathbf{2 0 1 0}$ & $\mathbf{2 0 1 1}$ & $\mathbf{2 0 1 2}$ & $\mathbf{2 0 1 3}$ & $\mathbf{2 0 1 4}$ & $\mathbf{2 0 1 5}$ \\
\hline RO & 36.0 & 35.0 & 28.4 & 25.2 & 26.3 & 25.9 & 25.1 & 26.1 & 28.7 \\
\hline NE & 30.9 & 29.3 & 24.5 & 21.6 & 24.2 & 23.0 & 21.4 & 22.1 & 23.9 \\
\hline SE & 41.8 & 42.5 & 34.7 & 29.7 & 28.3 & 32.1 & 31.3 & 30.9 & 34.1 \\
\hline
\end{tabular}

Source: authors' own calculations based on INS data

In the North-East Region, the low net use index of accommodation capacity, as against the national average and the other analysed region, also indicates other causes, such as: low accessibility to certain tourism zones, poor quality of services provided in certain tourism areas, unequal modernization of existing infrastructure, poor promotion of existing tourism potential. 
The net use index of tourism accommodation capacity in the South-East Region was clearly higher than that in the North-East Region throughout the investigated period. Moreover, in the South-East Region this index value was higher than the national average. The calculated values show that tourists are more attracted by the picturesque areas of this region, by the much more varied tourist offer and by the adequate conditions, which make them opt for this region as tourism destination. At the same time, the removal of inadequate structures and focusing the investments on those activities attractive for tourists led to a more efficient tourism in the region.

In the South-East Region, the average duration of tourists' stay was noticeably higher than that in the North-East Region and the national average.

The average length of stay, both nationwide and in the two regions had a decreasing trend. A short length of stay reveals a high mobility of tourists, their program including visits to several places, but with shorter stays in the same area. At the same time, this situation also has some other causes, factors that have contributed to the recent evolutions, namely: low incomes in the investigated period, poor quality of services for certain accommodation structures, diversified supply, both at national and international level, modification of tourism consumer behaviour.

Table 2. Average length of stay in Romania and in the two regions (number of days)

\begin{tabular}{|l|c|c|c|c|c|c|c|c|c|}
\hline & $\mathbf{2 0 0 7}$ & $\mathbf{2 0 0 8}$ & $\mathbf{2 0 0 9}$ & $\mathbf{2 0 1 0}$ & $\mathbf{2 0 1 1}$ & $\mathbf{2 0 1 2}$ & $\mathbf{2 0 1 3}$ & $\mathbf{2 0 1 4}$ & $\mathbf{2 0 1 5}$ \\
\hline RO & 3.0 & 2.9 & 2.8 & 2.6 & 2.6 & 2.5 & 2.4 & 2.4 & 2.4 \\
\hline NE & 2.1 & 2.1 & 2.1 & 2.0 & 2.0 & 2.0 & 1.9 & 1.8 & 1.8 \\
\hline SE & 3.9 & 3.7 & 3.6 & 3.3 & 3.3 & 3.3 & 3.3 & 3.4 & 3.4 \\
\hline
\end{tabular}

Source: authors' own calculations based on INS data

This type of stay is the equivalent of itinerant or circulation tourism. On the other hand, a longer length of stay reveals a lower mobility of tourists. This type of stay is equivalent to stay tourism and can be longer or shorter.

\section{Conclusions}

The two regions, North-East and South-East, are the largest regions of Romania in terms of surface area. On the territory of both regions there is a harmonious combination of relief forms, which gives the climatic specificity of the various areas.

In both regions, history, culture and tradition complement the natural environment, particularly attractive. Both in the North-East region and the South-East region there are numerous nature reserves and monuments, protected natural areas of national and international interest. Special factors in both regions are suitable for treating a wide range of conditions. Internally and internationally recognized viticulture areas are present in both development regions. The existence of the Black Sea coast and the Danube Delta on the territory of the South-East Development Region gives it a unique status in this region. All of this is an asset for tourism development, which is an 
important activity in a region's economy because "economic and social development is combined with tourism development" (Hontus, 2014).

The analysis of the main indicators of tourist activity in the two regions, during 20072015, highlighted certain aspects, synthetize below.

In the North-East Region the tourist receives structures had an upward trend in the period 2007-2015, while in the South-East region the trend was like that at national level, i.e. a downward trend. By comparison with the national level, an extremely important share of tourist receives structures was found in the two regions, in the investigated period.

The analysis by types of tourist receives structures revealed significant differences between the two regions: in the North-East Region the tourist and agro-tourist boarding houses prevailed, while the hotel and tourist villa structures prevailed in the South-East Region.

In the investigated period, the tourist accommodation capacity in operation followed an increasing trend in both regions.

In the year 2015, the number of tourists who arrived in the two development regions was higher than in 2007, a similar trend to that at national level. In the South-East Region, the number of tourist arrivals was higher compared to that in the North-East Region, while the number of Romanian tourists who arrived in the two regions prevailed.

The two indices that were calculated based on statistical data revealed the following:

- The net use index of accommodation capacity in the South-East region was higher than that of the North-East region and the national index. In dynamics, this index decreased both nationwide and in the two regions.

- The average length of stay had higher values in the South-East region, by comparison with the North-East region and the national average. Yet in dynamics, this index also decreased both nationwide and in the two investigated regions.

The fact that the net use index of accommodation capacity in the South-East region was higher than that in the North-East region and even than the national one means that the tourist potential of this region was much better capitalized. The downward dynamics of this cumulative indicator for the evaluation of the results of the tourism activity show that the tourism potential was used with low efficiency during the analysed period, both at the level of the two regions and at the national level.

Tourism in the two regions was affected by the absence of a general policy of guiding the sector. In order to correct this situation, it is necessary to promote both regions as tourist destinations as effectively as is possible and, thus, measures are needed in order to increase their recognition on the domestic and international tourism market, which is mandatory in the context of a strong international competitiveness. These actions should be the responsibility of the Ministry of Tourism and its territorial agencies. A strong marketing activity using all media channels are needed. The marketing must reach specific tourists/clients (targets) having in view the type of tourism promoted 
and which niche the local and national authorities choose to develop. Also, a strong marketing from investors is useful, both activities, from investors side and from state side having a synergy with the same final goal, a high level of competitiveness.

Government financial support by specific programs, coupled with EU tourism programs and private initiatives, will increase the competitiveness of the sector, both nationally and regionally.

These are the main ways that the Romanian tourism industry must follow to transform, develop and modernise itself, in a short period of time. The effects of the EU preaccession funds and programs proved the above-mentioned ideas. The evolution of the Romanian tourism before the EU accession is a good example that, there are positive results when the investors and the authorities follow the same way and have the same objectives. In the same time, our analysis of the tourism evolution after the EU accession proves that, the positive results are directly influences only by the investors' initiatives and authorities' attitude on one side, and on the other side there are negative direct influences only from external factors' pressure, like international economic and financial crisis.

\section{Conflict of interests}

The authors declare no conflict of interest.

\section{References}

1. Hontus, A. C. (2014). Analysis of tourism demand and supply-One of the essential elements of an area in tourism planning. Scientific Papers Series Management, Economic Engineering in Agriculture and Rural Development, 14(1), 147-152. http://managementjournal.usamv.ro/pdf/vol4_1/Art23.pdf

2. INS database. Retrieved January-March 2018 from www.tempo-online

3. Kravtsiv, V. S., Borshchevskyy, V. V., Voicilaş, D. M., Rusu, M. (2015). Rural areas of the Ukrainian-Romanian borderland: socio-economic development. Institute of Regional Research named after M.I. Dolishnij of the NAS of Ukraine. ISBN 978966-02-7866-0

4. Niță, I., Niță, C. (2008). Romania's touristic market. Realities. Mechanisms. Trends. Economic Publishing. ISBN 978-973-709-395-0

5. North-East ARD. (2014). North-East Regional Development Plan 2014-2020, Retrieved February 15, 2018 from http://www.adrnordest.ro/

6. North-East ARD. (2006). North-East Regional Development Plan 2007-2014 (Chapter 1.6. Tourism), Retrieved February 15, 2018 from http://www.adrnordest.ro/

7. North-East ARD. (2013). North-East Regional Development Strategy 2014-2020, Retrieved February 20, 2018 from http://www.fonduri-structurale.ro/ 
8. Popescu, A. (2016). Research on the economic efficiency in Romania's tourism. Scientific Papers Series Management, Economic Engineering in Agriculture and Rural Development, 16(1), 411-416. http://managementjournal.usamv.ro/pdf/ vol.16 1/Art64.pdf

9. Roşu, E. (2016). The tourism potential of Suceava county. Agricultural Economics and Rural Development, New Series, XIII(1), 107-118. https://ideas.repec.org/a/ iag/reviea/v13y2016ilp107-117.html

10. Romanian Government, Ministry of Culture. (2015). Order of the Minister of Culture no. 2828 of 2015, Retrieved March 10, 2018 from http://www.cultura.ro/ lista-monumentelor-istorice

11. Romanian Government. Ministry of Public Works, Development and Administration. (2007). Master Plan for national tourism of Romania 2007-2026, Retrieved March 5, 2018 from https://www.mdrap.ro/turism/studii

12. Stanciu, P. (2007). Study of tourist accommodation in the Suceava district. Revista de Turism, (4), 48-53.

13. Stănciulescu, G., Micu, C. (2009). Economy and management in tourism. Problems, projects and case studies. C.H. Beck Publishing. ISBN 978-973-115-487-9

14. South-East ARD. (2014). South-East Regional Development Plan 2014-2020, Retrieved March 10, 2018 from http://www.adrse.ro

15. Voicilaş, D. M. (2017). Opportunities and threats in North East Romania-SWOT analysis in Suceava and Botoşani counties. Agricultural Economics and Rural Development, New Series, XIV(2), 175-184. https://ideas.repec.org/a/iag/reviea/ v14y2017i2p175-184.html 